\title{
Retinoic Acid Induces Matrix Gla Protein Gene Expression in Human Cells*
}

\author{
M. LEONOR CANCELA AND PAUL A. PRICE† \\ Department of Biology, University of California-San Diego, La Jolla, California 9209.3
}

\begin{abstract}
The objective of this study was to investigate the possible regulation of the vitamin $\mathrm{K}$-dependent matrix Gla ( $\gamma$-carboxyglutamic acid) protein (MGP) by retinoic acid, a regulation suggested by the recent observation that the human MGP promoter has a perfect direct repeat which is nearly identical to the retinoic acid-responsive element in the retinoic acid receptor- $\beta$ gene. We report that retinoic acid strongly increases MGP mRNA levels in all human cells tested, including osteoblasts, articular cartilage chondrocytes, and fibroblasts. In
\end{abstract}

osteoblastic cells, MGP mRNA levels are increased by 25-fold at $1 \mu \mathrm{M}$ retinoic acid and achieve half-maximal levels at $0.1 \mu \mathrm{M}$ hormone. MGP is a small secreted protein of unknown function that is synthesized in a wide variety of vertebrate tissues. The present results suggest that part of the known actions of retinoic acid on skin, bone, cartilage, and other tissues in the human may be mediated by the stimulation of MGP synthesis and the consequent effect of increased MGP secretion on nearby target cells. (Endocrinology 130: 102-108, 1992)
$\mathrm{M}$ ATRIX Gla ( $\gamma$-carboxyglutamic acid) protein (MGP) is a 79-residue protein of unknown function that contains five residues of the vitamin $\mathrm{K}$-dependent calcium-binding amino acid, $\gamma$-carboxyglutamic acid (Gla) (1-3). MGP was first isolated from the matrix of bone, but is now known to be synthesized in all tissues tested, with the highest levels of synthesis in heart, kidney, lung, and cartilage $(4,5)$. We have recently determined the sequence of the human MGP gene and have identified a number of putative regulatory sequences in its promoter (6). One of the most interesting of these is the perfect direct repeat GGTGAACaaaa GGTGAAC, a sequence that shares a high degree of identity with the retinoic acid-responsive element in the human retinoic acid receptor- $\beta$ gene promoter, the sequence AGTGAACtttcGGTGAAC (7). The major objective of the present investigations was to evaluate the possible regulation of MGP expression by retinoic acid in a variety of human cell types. Because MGP is known to be induced by the active metabolite of vitamin $\mathrm{D}, 1,25$ dihydroxyvitamin $\mathrm{D}_{3}\left[1,25-(\mathrm{OH})_{2} \mathrm{D}_{3}\right]$ in rat osteosarcoma cells $(8,9)$, we have also investigated the effect of this hormone on MGP expression in human cells. In these studies we have used the related vitamin $\mathrm{K}$-dependent protein, bone Gla protein (BGP; osteocalcin), as an internal control, since BGP synthesis is known to be strongly induced by $1,25-(\mathrm{OH})_{2} \mathrm{D}_{3}$ in bone cells $(10-12)$, and a chloramphenicol acetyltransferase construct of the

Received April 26, 1991.

* This work was supported in part by USPHS Grant AR-25921.

† To whom requests for reprints should be addressed. human BGP promoter has been shown to be strongly induced by retinoic acid in rat osteosarcoma cells (13).

Retinoic acid is a natural metabolite of vitamin A that exerts profound effects on embryonic differentiation and development in a wide variety of systems $(14,15)$. Retinoic acid administration after birth also potently affects skin, bone, and other tissues (16-18), and many of the effects of vitamin A deficiency are currently thought to reflect the accompanying deficiency in retinoic acid activity (18). In the absence of retinoic acid supplementation, rats fed a vitamin A-deficient diet cease growth within 2 days, lose weight, and die within 28 days (19). In man, the systemic effects of vitamin A deficiency have been best characterized in the children of underdeveloped countries, where deficiency has been shown to cause reduced growth, blindness, and at least a 10 -fold increased mortality from all causes (20). In industrialized countries, several epidemiological studies have also revealed an inverse correlation between vitamin $\mathrm{A}$ intake and the incidence of several cancers $(21,22)$.

In spite of the profound effects of vitamin A deficiency on mortality and morbidity, most of which can be reversed in animal models by the administration of retinoic acid, relatively little is known about the biochemical actions of retinoic acid in children and adults. Retinoic acid is known to regulate the transcription of specific target genes by a ligand-dependent mechanism analogous to the action of steroid hormones and $1,25-(\mathrm{OH})_{2} \mathrm{D}_{3}(23$, 24 ), and a number of retinoic acid receptors have been identified $(25-28)$. However, most studies on the regulation of target gene expression by retinoic acid have been 
carried out in teratocarcinoma cells $(29,30)$, a model for stem cell differentiation in mammalian embryogenesis, and relatively few genes have been shown to be strongly up-regulated in other cells. These gene responses are the induction of $\mathrm{GH}$ in pituitary $\mathrm{GH}_{1}$ cells (31), transforming growth factor- $\beta_{2}$ in keratinocytes (32), complement factor $\mathrm{H}$ in $\mathrm{L} 929$ fibroblasts (33), retinoic acid receptor- $\beta$ in a number of cell types $(34,35)$, the alcohol dehydrogenase gene $\mathrm{ADH}_{3}$ in hepatoma Hep $3 \mathrm{~B}$ cells (36), and the transcription factor Zif 268 in fetal rat calvarial cells (37). The present investigations reveal that MGP is strongly induced by retinoic acid in bone cells, articular cartilage chondrocytes, and dermal fibroblasts.

\section{Materials and Methods}

\section{Materials}

${ }^{125} \mathrm{I}\left(4 \times 10^{18} \mathrm{cpm} / \mathrm{mol}\right)$ and $\left[\alpha^{-32} \mathrm{P}\right] \mathrm{dCTP}(>3,000 \mathrm{Ci} / \mathrm{mmol})$ were purchased from Amersham (Arlington Heights, IL). Cell culture medium, calf serum, PBS, antibiotics, fungisone, and trypsin were purchased from Irvine Scientific (Santa Ana, CA), and vitamin $C$ was purchased from Gibco (Grand Island, NY). The human osteosarcoma cell line MG-63 was purchased from American Type Culture Collection (CRL 1427, Rockville, MD). Normal human osteoblasts were obtained by the procedure of Gehron-Robey and Termine (38) from the calvaria of a 20week-old stillborn fetus and from the proximal femur trabecular bone removed during joint replacement of 68 - and $74-\mathrm{yr}$-old adults. Human articular cartilage chondrocytes from fetal, newborn, and osteoarthritic adult knee joints were a gift from Martin Lotz, and human foreskin fibroblasts were obtained from Charles Johnson. 1,25- $(\mathrm{OH})_{2} \mathrm{D}_{3}$ was a generous gift from M. R. Uskokovik at Hoffman-LaRoche (Nutley, NJ); retinoic acid (all-trans), actinomycin-D, and cycloheximide were purchased from Sigma (St. Louis, MO).

\section{Cell culture}

MG-63 cells were cultured in RPMI-1640, fetal osteoblasts in Coon's F-12, and adult osteoblasts in a 50:50 mixture of Minimum Essential Medium-Earle's salts and Ham's F-12; in each case, medium was supplemented with $10 \%$ newborn calf serum. Human chondrocytes from fetal, newborn, and adult articular cartilage were cultured in Dulbecco's Modified Eagle's-high glucose medium supplemented with $10 \%$ fetal calf serum, and foreskin fibroblasts were cultured in Minimum Essential Medium-Earle's salts medium supplemented with $10 \%$ newborn calf serum. For all cell types, medium was supplemented with $50 \mu \mathrm{g} / \mathrm{ml}$ vitamin C. All cells were transferred to serum-free medium at confluence and were maintained in this medium for $24 \mathrm{~h}$ before the beginning of each experiment. The medium in each $100-\mathrm{mm}$ plate was then replaced with 10 $\mathrm{ml}$ fresh serum-free medium supplemented with ethanol vehicle, $2.4 \mathrm{nM} 1,25-(\mathrm{OH})_{2} \mathrm{D}_{3}, 1 \mu \mathrm{M}$ retinoic acid, or a combination of both hormones. Every subsequent $24 \mathrm{~h}$, the conditioned medium was harvested, centrifuged to remove any cellular debris, and frozen for later analysis by RIA. At the same time, fresh serum-free medium containing the appropriate treat- ments was added to each plate of cells. Conditioned medium aliquots of $0.2 \mathrm{ml}$ or less were assayed for MGP by RIA, as previously described (39).

\section{RNA isolation/Northern analysis}

RNA was isolated by established methods $(40,41)$. Total RNA was fractionated on $1.4 \%$ agarose formaldehyde gels in a 3 -[ $N$-morpholino]propane sulfonic acid buffer and transferred to a nylon membrane $(0.45 \mu \mathrm{m}$; Nytran, Schleicher and Schuell, Keene, $\mathrm{NH})$, as previously described $(42,43)$. Relative mRNA levels were determined using the human BGP, ${ }^{1}$ human MGP (6), and rat $\beta$-actin (44) cDNA clones. The cDNAs were separated from the cloning vectors by gel purification, followed by electroelution (Elutrap, Schleicher and Schuell) and labeled with $\left[\alpha-{ }^{21} \mathrm{P}\right] \mathrm{dCTP}$ using a Random Primed DNA Labeling Kit (Boehringer Mannheim, Indianapolis, IN) to a specific activity of at least $1 \times 10^{8} \mathrm{cpm} / \mu \mathrm{g}$. Hybridization to RNA immobilized on Nytran was typically performed for $17 \mathrm{~h}$ at $42 \mathrm{C}$ with $1-5 \times$ $10^{6} \mathrm{cpm}$ DNA probe $/ \mathrm{ml} 50 \%$ formamide solution containing 5 $\times$ SSPE $\left[1 \times\right.$ SSPE is $180 \mathrm{mM} \mathrm{NaCl}, 10 \mathrm{mM} \mathrm{NaPO}_{4}(\mathrm{pH} 7.4)$, and $1 \mathrm{mM}$ EDTA], $5 \times$ Denhardt's, and $100 \mu \mathrm{g} / \mathrm{ml}$ salmon sperm DNA after prehybridization at $42 \mathrm{C}$ in the same solution without the cDNA probe. Filters were washed in 0.1-0.5 $\times$ SSPE containing $0.2 \%$ sodium dodecyl sulfate for $10 \mathrm{~min}$ at room temperature, followed by $1 \mathrm{~h}$ at $55 \mathrm{C}$. Autoradiography was performed at $-70 \mathrm{C}$ with Kodak XAR-5 film (Eastman Kodak, Rochester, NY) and DuPont Cronex Lightning Plus screens (DuPont, Wilmington, DE). RNA size markers (Bethesda Research Laboratories, Gaithersburg, MD) were run on adjacent gel lanes and stained with ethidium bromide. Probes were removed from the membranes by washing at $65 \mathrm{C}$ for 30 60 min with $50-60 \%$ formamide in $6 \times$ SSPE. After autoradiography, the relative intensities of the MGP, BGP, and $\beta$-actin mRNA bands in the autoradiographs were determined using an LKB Ultrascan XL Laser Densitometer (Rockville, MD). Small variations in the RNA loads were corrected by dividing the relative intensities obtained for MGP and BGP by those obtained for $\beta$-actin in the same lane.

\section{Results}

\section{Effect of retinoic acid and 1,25- $(\mathrm{OH})_{2} \mathrm{D}_{3}$ on $\mathrm{MGP}$ and} $B G P$ mRNA levels in osteoblastic cells

To evaluate the effects of retinoic acid and 1,25$(\mathrm{OH})_{2} \mathrm{D}_{3}$ on the expression of MGP and BGP, confluent cultures of osteoblastic cells were treated for various times with the respective hormones, and the levels of MGP and BGP mRNA were determined by Northern blot. As can be seen in Fig. 1, retinoic acid dramatically increased MGP mRNA levels in adult osteoblasts after 24,48 , and $72 \mathrm{~h}$ of treatment, while $1,25-(\mathrm{OH})_{2} \mathrm{D}_{3}$ had a small inhibitory effect on the basal levels of MGP mRNA. In contrast, both hormones induced BGP

\footnotetext{
'A human BGP cDNA spanning essentially the propeptide region of this protein was cloned from a MG $-63 \lambda \mathrm{gt} 11$ human cDNA library. The cDNA is 99 basepairs in length and encodes from amino acid -31 to +2 of the mature protein.
} 
Adult Osteoblasts

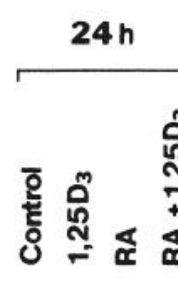

MGP
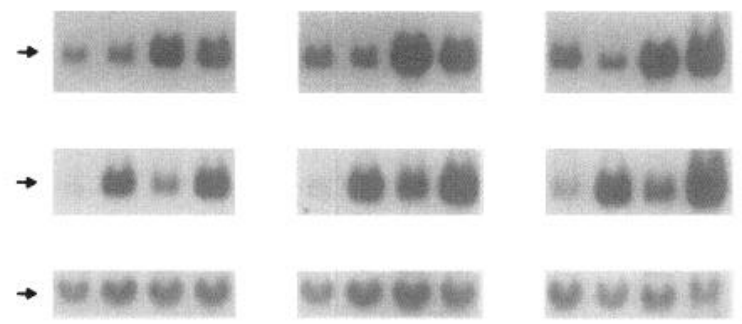

B-actin
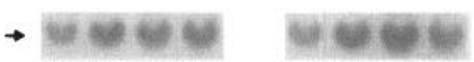

FIG. 1. Northern blot analysis of MGP and BGP mRNA levels in human adult osteoblasts. Cells were preincubated for $24 \mathrm{~h}$ in serumfree medium and then treated for 24,48 , and $72 \mathrm{~h}$ with ethanol vehicle (control), $2.4 \mathrm{nM} 1,25-(\mathrm{OH})_{2} \mathrm{D}_{3}\left(1,25 \mathrm{D}_{3}\right), 1 \mu \mathrm{M}$ retinoic acid (RA), or a combination of both hormones (RA $\left.+1,25 \mathrm{D}_{3}\right)$. Total RNA $(30 \mu \mathrm{g})$ from each condition was run on a $1.4 \%$ agarose-formaldehyde gel and then transferred to Nytran, as described in Materials and Methods. The membrane was first hybridized with a ${ }^{32} \mathrm{P}$-labeled human MGP cDNA then washed and reprobed with a ${ }^{32} \mathrm{P}$-labeled human BGP $\mathrm{cDNA}$. The amount of RNA loaded in each lane was monitored by hybridization with a rat $\beta$-actin cDNA. This experiment was repeated at 24,36 , and $72 \mathrm{~h}$ using cells from a different human donor, and in each case the hormone responses were essentially identical to those shown here.

mRNA, although the response was faster and stronger with $1,25-(\mathrm{OH})_{2} \mathrm{D}_{3}$ treatment. When these cells were treated with both hormones together, the BGP mRNA response to $1,25-(\mathrm{OH})_{2} \mathrm{D}_{3}$ was stimulated by retinoic acid at 24,48 , and $72 \mathrm{~h}$, while the MGP mRNA response to retinoic acid was not significantly affected by 1,25 $(\mathrm{OH})_{2} \mathrm{D}_{3}$.

Retinoic acid treatment caused a similar increase in MGP mRNA levels in the MG-63 human osteosarcoma cell line (Fig. 2). The increase in MGP mRNA levels in retinoic acid-treated cells relative to that in untreated control cells varied from 8 - to 35 -fold in different experiments. This variation in apparent response was primarily caused by as yet unexplained differences in basal MGP mRNA expression among these experiments. In contrast to adult osteoblasts, MGP mRNA expression was also strongly induced by $1,25-(\mathrm{OH})_{2} \mathrm{D}_{3}$, although the response was somewhat slower than that of retinoic acid. BGP synthesis was again strongly induced by 1,25 $(\mathrm{OH})_{2} \mathrm{D}_{3}$ in the MG-63 cells (Fig. 2), but in contrast with normal osteoblasts, BGP mRNA was not induced by retinoic acid.

Effect of retinoic acid on MGP $m R N A$ levels in fibroblasts, chondrocytes, and fetal osteoblasts

To further evaluate the significance of the strong MGP response to retinoic acid in MG-63 cells and adult oste-
MG-63 Human Osteosarcoma

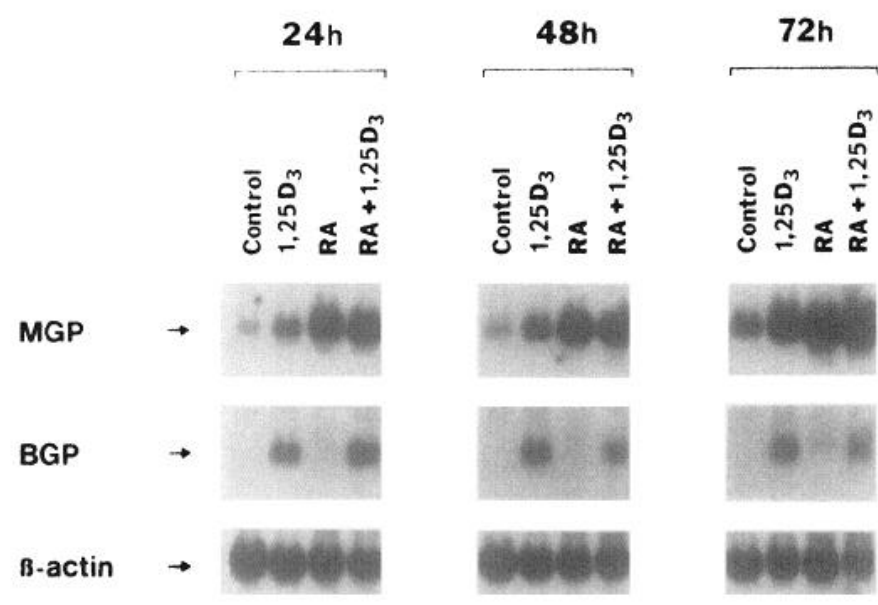

FIG. 2. Northern blot analysis of MGP and BGP mRNA levels in MG63 human osteosarcoma cells. Cells were preincubated for $24 \mathrm{~h}$ in serum-free medium and then treated for 24,48 , and $72 \mathrm{~h}$ with ethanol vehicle (control), $2.4 \mathrm{nM} 1,25-(\mathrm{OH})_{2} \mathrm{D}_{3}\left(1,25 \mathrm{D}_{3}\right), 1 \mu \mathrm{M}$ retinoic acid (RA), or a combination of both hormones (RA $\left.+1,25 \mathrm{D}_{3}\right)$. Total RNA $(30 \mu \mathrm{g})$ from each condition was analyzed as described in Fig. 1. The 24 and $48 \mathrm{~h}$ time points of this experiment were repeated once, and at both times the hormone responses were essentially identical to those shown here.

oblasts, the effect of retinoic acid on MGP mRNA levels was also measured by Northern blot in fibroblasts, articular cartilage chondrocytes, and fetal osteoblasts. As shown in Fig. 3, retinoic acid strongly increased MGP mRNA levels in each cell type after 24 and $48 \mathrm{~h}$ of treatment. An equivalently strong increase in MGP mRNA levels was also seen in chondrocytes from newborn and osteoarthritic adult articular cartilage after 24 and $48 \mathrm{~h}$ of retinoic acid treatment (data not shown). Treatment with $1,25-(\mathrm{OH})_{2} \mathrm{D}_{3}$ alone did not increase MGP mRNA levels in any of these cells, although 1,25$(\mathrm{OH})_{2} \mathrm{D}_{3}$ treatment did attenuate the retinoic acid response in fetal osteoblasts and chondrocytes (Fig. 3) and in fibroblasts (data not shown). In this experiment the level of MGP antigen in the conditioned medium of fetal osteoblasts was sufficient for measurement by RIA. After $48 \mathrm{~h}$ of treatment with retinoic acid, MGP levels in the medium of fetal osteoblasts were 6.4-fold higher than those in the medium of untreated cells, while MGP levels in the medium of cells treated with $1,25-(\mathrm{OH})_{2} \mathrm{D}_{3}$ plus retinoic acid were only 3.6 -fold higher than those in the medium of untreated cells (data not shown). For comparison, densitometer scanning of the autoradiograph for fetal osteoblasts revealed that MGP mRNA levels were 8.6 -fold higher in cells treated for $48 \mathrm{~h}$ with retinoic acid (Table 1) and 5.8-fold higher in cells treated for $48 \mathrm{~h}$ with retinoic acid plus $1,25-(\mathrm{OH})_{2} \mathrm{D}_{3}$. 
FIG. 3. Northern blot analysis of MGP mRNA levels in human fetal osteoblasts, fetal chondrocytes, and newborn fibroblasts. Cells were preincubated in serumfree medium for $24 \mathrm{~h}$ and then treated for 24 and $48 \mathrm{~h}$ with ethanol vehicle (control), $2.4 \mathrm{nM} 1,25-(\mathrm{OH})_{2} \mathrm{D}_{3}\left(1,25 \mathrm{D}_{3}\right)$, $1 \mu \mathrm{M}$ retinoic acid (RA), or a combination of both hormones (RA $+1,25 \mathrm{D}_{3}$ ). Total RNA $(30 \mu \mathrm{g})$ from each condition was analyzed by Northern blot, as described in Materials and Methods, and the membranes were hybridized with ${ }^{32} \mathrm{P}$-labeled human MGP and rat $\beta$-actin cDNAs. This experiment was repeated at least once for each cell type, and in each case the hormone responses were essentially identical to those shown here.

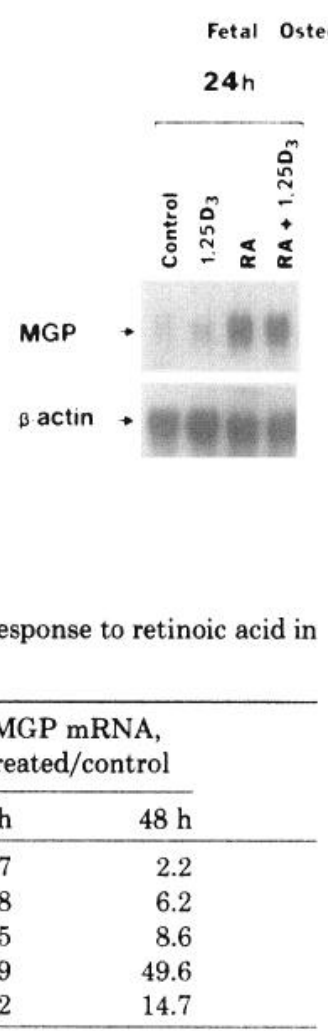

TABLE 1. Comparison of the MGP mRNA response to retinoic acid in different cells

\begin{tabular}{lrr}
\hline \multirow{2}{*}{ Cell } & \multicolumn{2}{c}{$\begin{array}{c}\text { MGP mRNA, } \\
\text { treated/control }\end{array}$} \\
\cline { 2 - 3 } & $24 \mathrm{~h}$ & $\mathbf{4 8 \mathrm { h }}$ \\
\hline Human osteoblasts & 4.7 & 2.2 \\
MG-63 & 8.8 & 6.2 \\
Fetal osteoblasts & 6.5 & 8.6 \\
Fetal chondrocytes & 11.9 & 49.6 \\
Fibroblasts & 6.2 & 14.7 \\
\hline
\end{tabular}

The autoradiographs shown in Figs. 1-3 were scanned by densitometer in order to quantitate the effect of retinoic acid on MGP mRNA levels (see Materials and Methods for details). The results are given as MGP mRNA in cells treated for the indicated times with retinoic acid divided by MGP mRNA in cells treated with ethanol vehicle for the same time.

Dose dependence and time course of the MGP $m R N A$ response to retinoic acid

The time course and dose dependence of the MGP mRNA response to retinoic acid were evaluated in MG63 osteosarcoma cells, since these cells grow rapidly and display a retinoic acid response apparently identical to that in the normal cells. As seen in Fig. 4, MGP mRNA levels were elevated 3 -fold by $6 \mathrm{~h}$ of treatment with retinoic acid and continued to increase over the $48 \mathrm{~h}$ of hormone treatment. As shown in Fig. 5, the MGP mRNA response was maximal at $1 \mu \mathrm{M}$ hormone, and half of the maximal response was attained at $0.1 \mu \mathrm{M}$. Retinoic acid caused a substantial reduction in cell number at the highest dose tested, which probably accounts for the reduced MGP mRNA level in these cells.

Effect of inhibitors of RNA and protein synthesis on the $M G P$ mRNA response to retinoic acid

As can be seen in Fig. 6, cotreatment of MG-63 cells with retinoic acid and either the protein synthesis inhibitor cycloheximide or the RNA synthesis inhibitor acti-
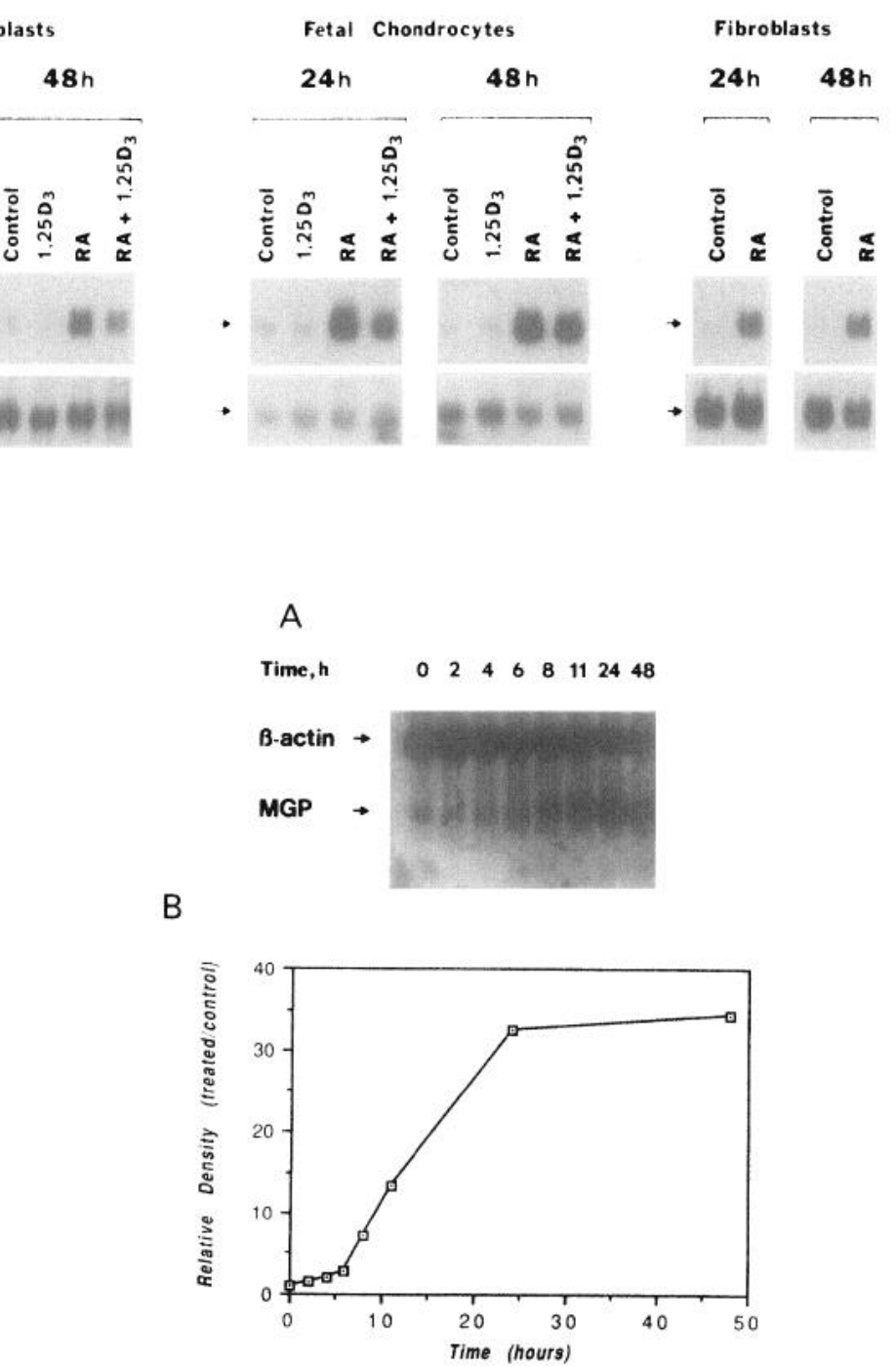

FIG. 4. Time course of the stimulation of MGP mRNA by retinoic acid. Cells were preincubated in serum-free medium for $24 \mathrm{~h}$ and then treated for the indicated periods of time with $1 \mu \mathrm{M}$ retinoic acid or ethanol vehicle. Total RNA $(20 \mu \mathrm{g})$ from each time point was analyzed by Northern blot, as described in Materials and Methods, and the membranes were hybridized with ${ }^{32} \mathrm{P}$-labeled human MGP and rat $\beta$ actin cDNAs. A, Autoradiograph of the Northern blot. B, Quantification of the results obtained by Northern analysis. The relative amount of radioactivity specifically bound to the filters was determined by a densitometric scan of the autoradiographs (see Materials and Methods)). Since there was no significant change in the level of MGP mRNA in the control cultures over this time period (data not shown), all control values were averaged. The final results are expressed as density for each time of retinoic acid treatment divided by the control value average. This experiment was repeated twice, and in both cases the time course of MGP mRNA inductior. was essentially identical to that shown here.

nomycin-D completely blocked the increase in MGP mRNA levels. These observations indicate that the retinoic acid-dependent increase in MGP mRNA levels 


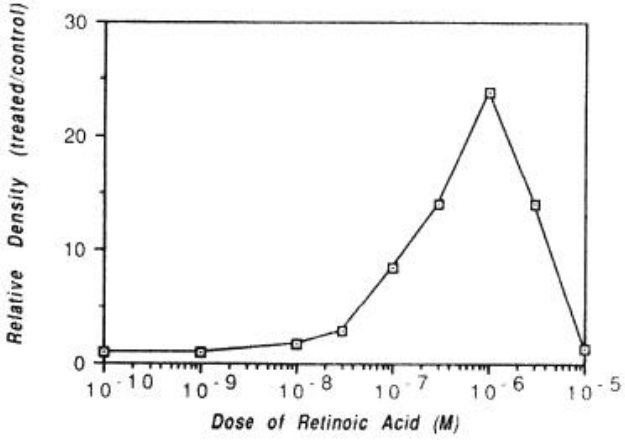

FIG. 5. Dose-dependent induction of MGP mRNA by retinoic acid. MG-63 cells were preincubated for $24 \mathrm{~h}$ in serum-free medium and then treated with either ethanol vehicle or various concentrations of retinoic acid for 2 days. Total RNA $(30 \mu \mathrm{g})$ from each condition was analyzed by Northern blot, as described in Materials and Methods, and the membranes were simultaneously hybridized with ${ }^{32} \mathrm{P}$-labeled human MGP and rat $\beta$-actin cDNAs. The relative amount of radioactivity specifically bound to the filters was determined by a densitometric scan of the autoradiographs (see Materials and Methods). Results are expressed as the MGP mRNA hybridization density for each concentration of retinoic acid divided by the density in untreated control cells. This experiment was repeated once, with essentially identical results.

probably requires both RNA and protein synthesis. Since actinomycin-D did not significantly reduce MGP mRNA levels in control cells, it is also probable that the halflife of MGP mRNA turnover is substantially longer than the $14 \mathrm{~h}$ of actinomycin-D treatment.

\section{Discussion}

The present results suggest that MGP could mediate some of the known effects of retinoic acid on cell growth and differentiation in a wide variety of human tissues. Retinoic acid strongly stimulated MGP mRNA levels in all human cells tested, which include osteoblasts, chondrocytes, and fibroblasts from fetal, newborn, and adult tissues, and it seems probable that MGP is also regulated by retinoic acid in the many additional cells and tissues that express the protein $(4,5)$. The function of MGP itself is presently unknown. It is small (79 residues), has five residues of the vitamin $\mathrm{K}$-dependent $\mathrm{Ca}^{2+}$-binding amino acid $\gamma$-carboxyglutamic acid, and has two conserved dibasic sequences, one of which is a site of proteolytic processing $(2,3)$. The protein was first discovered as a component of the bone morphogenetic material (1), although it is not presently considered to be critical for bone induction, and has been identified by differential screening as a gene that is strongly expressed by breast cancer cells (45). We speculate that MGP is a locally acting regulator of cell growth and/or differentiation in a wide variety of tissues, and that a part of the action of retinoic acid on different tissues is achieved by the stimulation of MGP synthesis and the subsequent effect of increased MGP secretion on nearby target cells.

It seems probable that retinoic acid increases MGP
A
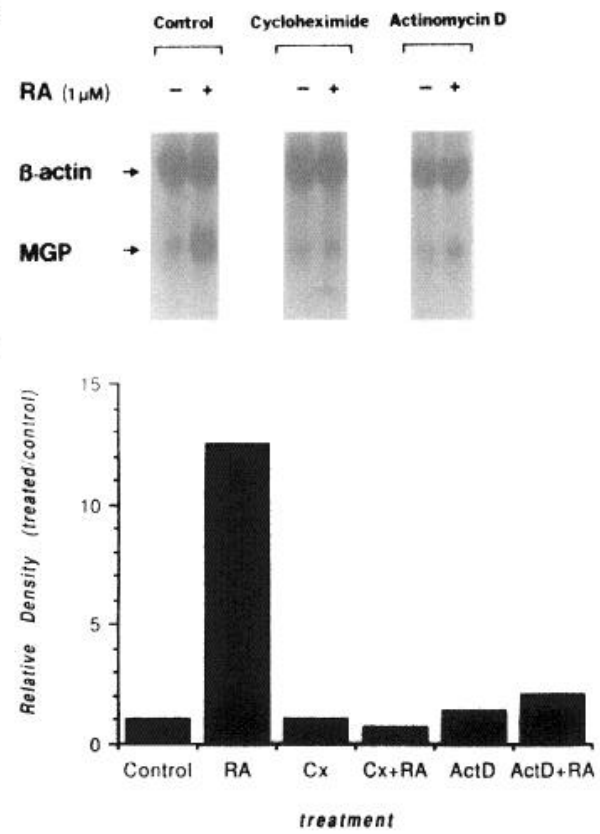

FIG. 6. Effects of inhibitors of RNA and protein synthesis on the MGP mRNA response to retinoic acid. Cells were preincubated for $24 \mathrm{~h}$ in serum-free medium and then treated for $14 \mathrm{~h}$ with $\mu \mathrm{M}$ retinoic acid (RA) or ethanol vehicle (control) in the presence or absence of $5 \mu \mathrm{M}$ cycloheximide $(\mathrm{Cx})$ or $0.05 \mu \mathrm{M}$ actinomycin-D (Act D). Total cellular RNA $(30 \mu \mathrm{g})$ from each treatment was analyzed by Northern blot, as described in Materials and Methods, and the membrane was simultaneously hybridized with ${ }^{32} \mathrm{P}$-labeled human MGP and rat $\beta$-actin cDNAs. A, Autoradiograph of the Northern blot. B, Quantification of the results obtained by Northern analysis. The relative amount of radioactivity specifically bound to the filter was determined by densitometric scan of the autoradiograph (see Materials and Methods). The results are given as the MGP mRNA density for each treatment divided by the density in the untreated control. This experiment was repeated with MG-63 cells after $24 \mathrm{~h}$ of treatment and with human fibroblasts after $14 \mathrm{~h}$ of treatment; in each instance, inhibitors of RNA and protein synthesis blocked the MGP response to retinoic acid without significantly affecting basal MGP mRNA levels.

mRNA levels by binding to a retinoic acid receptor, which, in turn, binds to the putative retinoic acid-responsive element in the human MGP gene promoter and activates MGP gene transcription. Most of the genes known to be induced by retinoic acid are thought to be regulated at the transcriptional level by this mechanism $(7,33)$, and the putative retinoic acid-responsive element in the MGP gene promoter is essentially identical to the well characterized retinoic acid-responsive element present in the human retinoic acid receptor- $\beta$ gene promoter (7). In addition, the time course and dose dependence of the MGP mRNA response to retinoic acid are essentially identical to those in genes known to be activated transcriptionally by this hormone $(31,33)$. We have shown that $0.05 \mu \mathrm{M}$ of the transcriptional inhibitor actinomycin-D does, in fact, block the induction of MGP mRNA by retinoic acid. The induction of MGP mRNA is also 
prevented by $5 \mu \mathrm{M}$ of the protein synthesis inhibitor cycloheximide. Cycloheximide blocks or significantly diminishes the action of retinoic acid on several genes that have been shown by other evidence to be regulated at the transcriptional level by this hormone $(30,46)$, and therefore, it is possible that MGP and other genes induced by retinoic acid may require a rapidly turned over transcriptional factor for the retinoic acid receptor-dependent induction of transcription. We are presently investigating the possible functions of the putative retinoic acid-responsive element in the MGP gene promoter in the MGP mRNA response to this hormone.

Our results show that $1,25-(\mathrm{OH})_{2} \mathrm{D}_{3}$ by itself has no significant effect on MGP gene expression in any normal human cell analyzed, but strongly increases MGP mRNA in the human osteosarcoma cell MG-63. A similar strong induction of MGP mRNA by $1,25-(\mathrm{OH})_{2} \mathrm{D}_{3}$ has been reported in UMR 106 and ROS 17/2 rat osteosarcoma cells $(8,9)$. The absence of a MGP mRNA response to $1,25-(\mathrm{OH})_{2} \mathrm{D}_{3}$ in adult osteoblasts cannot be due to an absence of vitamin $\mathrm{D}$ receptors, since there is a strong BGP mRNA response to $1,25-(\mathrm{OH})_{2} \mathrm{D}_{3}$ in these cells. One possible explanation for the absence of MGP mRNA induction in normal adult osteoblasts could be that there is a fundamental difference in the $1,25-(\mathrm{OH})_{2} \mathrm{D}_{3}$ response pattern between tumorigenic and nontumorigenic cells, a difference that has been postulated in earlier studies on the hormonal response of bone cells (47). Although $1,25-(\mathrm{OH})_{2} \mathrm{D}_{3}$ did not induce MGP mRNA in normal human cells, it did attenuate the MGP mRNA response to retinoic acid in chondrocytes, fibroblasts, and fetal osteoblasts. The antagonism between vitamins $A$ and $D$ has been noted in animal studies (48) and could reflect heterodimer formation between these related receptors $(23,24)$, as has been shown for thyroid and retinoic acid receptors (49).

In the present report, $1,25-(\mathrm{OH})_{2} \mathrm{D}_{3}$ was found to increase the levels of BGP mRNA in adult osteoblasts and in the MG-63 human osteosarcoma cell line. Although the induction of BGP mRNA by $1,25-(\mathrm{OH})_{2} \mathrm{D}_{3}$ in normal human osteoblasts has not been reported previously, this result is consistent with the increase in BGP secretion in response to $1,25-(\mathrm{OH})_{2} \mathrm{D}_{3}$ in these cells (11) and with previous studies on the $\mathrm{BGP} \mathrm{mRNA}$ response to 1,25 $(\mathrm{OH})_{2} \mathrm{D}_{3}$ in MG-63 and other osteoblastic cells $(9,50$, 51). In normal osteoblasts, retinoic acid alone also significantly increased BGP mRNA levels, although this response was somewhat delayed and less strong than the BGP mRNA induction by $1,25-(\mathrm{OH})_{2} \mathrm{D}_{3}$ in these cells. This result is in good agreement with previous studies on the hormonal induction of BGP at the protein level in these cells (52), and with recent investigations which have shown that retinoic acid as well as $1,25-(\mathrm{OH})_{2} \mathrm{D}_{3}$ can induce transcription of a chimeric construct in which a fragment of the human BGP gene promoter is fused to the bacterial chloramphenicol acetyltransferase gene and transfected into the ROS $17 / 2$ rat osteosarcoma cell line (13). The failure of retinoic acid to increase BGP mRNA in MG-63 cells could again reflect an altered control of gene transcription by steroid hormones in tumorigenic cells.

\section{Acknowledgments}

The authors wish to thank Dr. J. S. Johansen for kindly providing the cultures of the normal adult osteoblasts, and $\mathrm{M}$. $\mathrm{K}$. Williamson for critical comments in this manuscript.

\section{References}

1. Price PA, Urist MR, Otawara Y 1983 Matrix Gla protein, a new $\gamma$-carboxyglutamic acid-containing protein which is associated with the organic matrix of bone. Biochem Biophys Res Commun 117:765-771

2. Price PA, Williamson MK 1985 Primary structure of bovine matrix Gla protein, a new vitamin K-dependent bone protein. J Biol Chem 260:14971-14975

3. Price PA, Fraser JD, Metz-Virca G 1987 Molecular cloning of matrix Gla protein: implications for substrate recognition by the vitamin K-dependent $\gamma$-carboxylase. Proc Natl Acad Sci USA 84:8335-8339

4. Fraser JD, Price PA 1988 Lung, heart, and kidney express high levels of mRNA for the vitamin K-dependent matrix Gla protein. Implications for the possible functions of matrix Gla protein and for the tissue distribution of the $\gamma$-carboxylase. $J$ Biol Chem 263:11033-11036

5. Hale JE, Fraser JD, Price PA 1988 The identification of matrix Gla protein in cartilage. J Biol Chem 263:5820-5824

6. Cancela L, Hsieh C-L, Francke U, Price PA 1990 Molecular structure, chromosome assignment and promoter organization of the human matrix Gla protein gene. J Biol Chem 265:15040-15048

7. de The H, Vivanco-Ruiz MM, Tiollais $\mathbf{P}$, Stunnenberg H, DeJean A 1990 Identification of a retinoic acid responsive element in the retinoic acid receptor $\beta$ gene. Nature 343:177-180

8. Fraser JD, Otawara Y, Price PA 1988 1,25-Dihydroxyvitamin $D_{3}$ stimulates the synthesis of matrix Gla protein by osteosarcoma cells. J Biol Chem 263:911-916

9. Fraser JD, Price PA 1990 Induction of matrix Gla protein synthesis during prolonged 1,25-dihydroxyvitamin $\mathrm{D}_{3}$ treatment of osteosarcoma cells. Calcif Tissue Int 46:270-279

10. Price PA, Baukol SA 1980 1,25-Dihydroxyvitamin $D_{3}$ increases synthesis of the vitamin K-dependent bone protein by osteosarcoma cells. J Biol Chem 255:11660-11663

11. Beresford JN, Gallagher JA, Poser JW, Russell RGG 1984 Production of osteocalcin by human bone cells in vitro. Effects of 1,25$(\mathrm{OH})_{2} \mathrm{D}_{3}, 24,25(\mathrm{OH})_{2} \mathrm{D}_{3}$, parathyroid hormone, and glucocorticoids. Metab Bone Dis Kel Kes 5:229-234

12. Franceschi RT, Romano PR, Park K-Y 1988 Regulation of type I collagen synthesis by 1,25 -dihydroxyvitamin $D_{3}$ in human osteosarcoma cells. J Biol Chem 263:18938-18945

13. Schüle R, Umesono K, Mangelsdorf DJ, Bolado J, Wesley Pike J, Evans RM 1990 Jun-Fos and receptors for vitamin $A$ and $D$ recognize a common response element in the human osteocalcin gene. Cell 61:497-504

14. Roberts AB, Sporn MB 1984 Cellular biology and biochemistry of the retinoids. In: Sporn MB, Roberts AB, Goodman DS (eds) The Retinoids. Academic Press, New York, vol 2:210-286

15. Smith SM, Pang K, Sundin O, Wedden SE, Thaller C, Eichele G 1989 Molecular approaches to vertebrate limb morphogenesis. Development [Suppl]:121-131

16. Elias PM 1986 Epidermal effects of retinoids: supramolecular observations and clinical implications. J Am Acad Dermatol 
15:797-809

17. Lawson JP, McGuire J 1987 The spectrum of skeletal changes associated with long-term administration of 13-cis-retinoic acid. Skeletal Radiol 16:91-97

18. Biesalski HK 1989 Comparative assessment of the toxicology of vitamin $A$ and retinoids in man. Toxicology 57:117-161

19. Anzano MA, Lamb AJ, Olson JA 1979 Growth, appetite, sequence of pathological signs and survival following the induction of rapid, synchronous vitamin A deficiency in the rat. J Nutr 109:1419-1431

20. Sommer A 1989 Large dose vitamin A to control vitamin A deficiency. Int J Vitam Nutr Res [Suppl] 30:37-41

21. Wald N, Idle M, Boreham J, Bailey A 1980 Low serum-vitamin-A and subsequent risk of cancer. Lancet ii:813-815

22. Kark JD, Smith AH, Hames CG 1982 Serum retinol and the inverse relationship between serum cholesterol and cancer. $\mathrm{Br}$ Med $\mathrm{J}$ 284:152-154

23. Evans RM 1988 The steroid and thyroid hormone receptor superfamily. Science 240:889-895

24. Beato M 1989 Gene regulation by steroid hormones. Cell $56: 335-$ 344

25. Giguère V, Ong ES, Segui P, Evans RM 1987 Identification of a receptor for the morphogen retinoic acid. Nature 330:624-629

26. Brand N, Petkovich M, Krust A, Chambon P, de The H, Marchio A, Tiollais P, DeJean A 1988 Identification of a second human retinoic acid receptor. Nature 332:850-853

27. Krust A, Kastner P, Petkovich M, Zelent A, Chambon P 1989 A third human retinoic acid receptor, hRAR- $\gamma$. Proc Natl Acad Sci USA 86:5310-5314

28. Mangelsdorf DJ, Ong ES, Dyck JA, Evans RM 1990 Nuclear receptor that identifies a novel retinoic acid response pathway. Nature 345:224-229

29. Wang S-Y, Gudas LJ 1990 A retinoic acid-inducible mRNA from F9 teratocarcinoma cells encodes a novel protease inhibitor homologue. J Biol Chem 265:15818-15822

30. Tomomura M, Kadomatsu K, Matsubara S, Muramatsu T 1990 A retinoic acid-responsive gene, $\mathrm{MK}$, found in the teratocarcinoma system. J Biol Chem 265:10765-10770

31. Bedo G, Santisteban P, Aranda A 1989 Retinoic acid regulates growth hormone gene expression. Nature 339:231-234

32. Glick AB, Flanders KC, Danielpour D, Yuspa SH, Sporn MB 1989 Retinoic acid induces transforming growth factor- $\beta 2$ in cultured keratinocytes and mouse epidermis. Cell Regul 1:87-97

33. Muñoz-Cánoves $P$, Vik DP, Tack BF 1990 Mapping of a retinoic acid-responsive element in the promoter region of the complement factor $\mathrm{H}$ gene. $J$ Biol Chem 265:20065-20068

34. de The H, Marchio A, Tiollais P, Dejean A 1989 Differential expression and ligand regulation of the retinoic acid receptor $\alpha$ and $\beta$ genes. EMBO J 8:429-433

35. Sucov HM, Murakami KK, Evans RM 1990 Characterization of an autoregulated response element in the mouse retinoic acid receptor type $\beta$ gene. Proc Natl Acad Sci USA 87:5392-5396

36. Duester G, Shean ML, McBride MS, Stewart MJ 1991 Retinoic acid response element in the human alcohol dehydrogenase gene ADH3: implications for regulation of retinoic acid synthesis. Mol
Cell Biol 11:1638-1646

37. Suva LJ, Ernst M, Rodan GA 1991 Retinoic acid increases zif268 early gene expression in rat preosteoblastic cells. Mol Cell Bivl 11:2503-2510

38. Gehron-Robey P, Termine JD 1985 Human bone cells in vitro. Calcif Tissue Int 37:453-460

39. Otawara Y, Price PA 1986 Developmental appearance of matrix Gla protein during calcification in the rat. J Biol Chem 261:10828 10832

40. Chirgwin JM, Przybyla AE, MacDonald RJ, Rutter WJ 1979 Isolation of biologically active ribonucleic acid from sources enriched in ribonuclease. Biochemistry 18:5294-5299

41. Chomczynski P, Sacchi N 1987 Single-step method of RNA isolation by acid guanidinium thiocyanate-phenol-chloroform extraction. Anal Biochem 162:156-159

42. Selden RF 1987-1990 Analysis of RNA by Northern hybridization. In: Ausubel FM, Brent R, Kingston RE, Moore DD, Seidman JG, Smith JA, Struhl K (eds) Current Protocols in Molecular Biology, unit 4.9. Greene and Wiley Interscience, Brooklyn, pp 4.9.1-4.9.8

43. Sambrook J, Fritsch EF, Maniatis T 1989 Molecular Cloning - A Laboratory Manual, ed 2. Cold Spring Harbor Laboratory Press, Cold Spring Harbor, pp 7.43-7.50

44. Nudel U, Katcoff D, Zakut R, Shani M, Carmon Y, Finer M, Czosnek H, Ginsburg I, Yaffe D 1982 Isolation and characterization of rat skeletal muscle and cytoplasmic actin genes. Proc Natl Acad Sci USA 79:2763-2767

45. Chen L, O'Bryan JP, Smith HS, Liu E 1990 Overexpression of matrix Gla protein mRNA in malignant human breast cells: isolation by differential cDNA hybridization. Oncogene 5:1391-1395

46. Gudas LJ, Wang SY 1986 The regulation of collagen type IV $(\alpha 1)$ and other genes during the retinoic acid induced differentiation of wild type and mutant mouse teratocarcinoma stem cells. Prog Clin Biol Res 226:181-189

47. Lee KL, Petkovich PM, Heersche JNM 1988 The effects of sodium butyrate on the retinoic acid-induced changes in 1,25-dihydroxyvitamin $\mathrm{D}_{3}$ receptors in tumorigenic and nontumorigenic bone derived cell lines. Endocrinology 122:2399-2406

48. Vedder EB, Rosenberg C 1938 Concerning the toxicity of vitamin A. J Nutr $16: 57-68$

49. Glass CK, Lipkin SM, Devary OV, Rosenfeld MG 1989 Positive and negative regulation of gene transcription by a retinoic acidthyroid hormone receptor heterodimer. Cell 59:697-708

50. Mahonen A, Pirskanen A, Keinänen R, Mäenpää PH 1990 Effect of $1,25-(\mathrm{OH})_{2} \mathrm{D}_{3}$ on its receptor mRNA levels and osteocalcin synthesis in human osteosarcoma cells. Biochim Biophys Acta 1048:30-37

51. Theofan G, Price PA 1989 Bone Gla protein mRNA is regulated by both 1,25-dihydroxyvitamin $\mathrm{D}_{3}$ and cAMP in rat osteosarcoma cells. Mol Endocrinol 3:36-43

52. Evans DB, Bunning RAD, Russell RGG 1988 Studies on the interaction between retinoic acid and $1,25-(\mathrm{OH})_{2} \mathrm{D}_{3}$ on human bone-derived osteoblast-like cells. In: Norman AW, Schaefer K, Grigoleit HG, von Herrath D (eds) Vitamin D: Molecular and Clinical Endocrinology. de Gruyter, Berlin and New York, pp 606607 